\title{
Activity of Tabanids (Insecta: Diptera: Tabanidae) Attacking the Reptiles Caiman crocodilus (Linn.) (Alligatoridae) and Eunectes murinus (Linn.) (Boidae), in the Central Amazon, Brazil
}

\author{
Ruth LM Ferreira ${ }^{+}$, Augusto L Henriques, José A Rafael
}

Coordenação de Pesquisas em Entomologia, Instituto Nacional de Pesquisas da Amazônia, Caixa Postal 478, 69011-970 Manaus, AM, Brasil

Tabanid females are better known as hematophagous on man and other mammals, and linked to mechanical transmission of parasites. The association between tabanids and reptiles is poorly known, but has been gaining more corroboration through experiments and occasional observation in the tropics. The present study was conducted at a military base (CIGS/BI-2), situated $54 \mathrm{~km}$ from Manaus, Amazonas, in a small stream in a clearing (02\%45'33"S; 59051'03”W). Observations were made monthly, from April 1997 to March 1998, during two consecutive days. At the same time, other vertebrate animals were offered, including humans. However in this paper only data obtained on a common caiman, Caiman crocodilus (Linn.), and an anaconda, Eunectes murinus (Linn.), in diurnal observations from 05:30 a.m. to 18:30 p.m., will be discussed. A total of 254 tabanid specimens were collected, 40 from the anaconda and 214 from the caiman. Four tabanid species were recorded on these two reptiles: Stenotabanus cretatus Fairchild, S. bequaerti Rafael et al., Phaeotabanus nigriflavus (Kröber) and Tabanus occidentalis Linn. Diurnal activities showed species-specific patterns. The first three species occurred only in the dry season. T. occidentalis occurred during the whole observation period, and with increased frequency at the end of the dry season. We observed preferences for body area and related behavior of the host. Observations on the attack of tabanids on one dead caiman are also presented.

Key words: Tabanidae - horse fly - hematophagy - common caiman - anaconda - tropical forest - Amazon Basin

Blood-feeding of tabanids (Diptera: Tabanidae) has been the subject of occasional observations and experiments in the tropics. This is because the females of tabanids are known as ectoparasites of humans and other mammals, and thus are likely to transmit pathogens mechanically during interrupted feeding on different hosts. The association of tabanids with reptiles was described briefly by Leclercq (1952) apud Oldroyd (1954). More recently, Medem (1981) reported ten tabanid species attacking caimans in Colombia, but only four fed exclusively or preferentially on caimans. Philip (1983) reported one species attacking turtles in the Galapagos islands and in 1986 reported four tabanid species attacking anacondas in the Tambopata River, Peru. Barros (1996) observed one species flying around alligators at Corumbá, Brazil. Oliveira (1998) collected three tabanid species flying around alligators near the site were the present study was conducted. Henriques et al. (2000) recorded four species attacking caimans in the Central Amazon.

The present study was undertaken to verify the diurnal activity and seasonality of tabanids captured using two reptile host-species: the common caiman, Caiman crocodilus (Alligatoridae) and the anaconda, Eunectes murinus (Boidae). We observed parasite/host-specificity, frequency of landing and blood feeding on different body parts, host defense behavior and we studied the relationship between tabanid species occurrence, temperature and relative humidity.

\footnotetext{
Financial support: PPI-1-3070 (MCT/INPA)

${ }^{+}$Corresponding author. Fax: + 55-92-643.3195. E-mail: ruth@inpa.gov.br

Received 7 May 2001

Accepted 24 July 2001
}

\section{MATERIALS AND METHODS}

Fieldwork was carried out in cooperation with the Brazilian Army at the Center for Instruction of Forest War (Centro de Instrução de Guerra na Selva, Base for Instruction 2 (BI-2), about $54 \mathrm{~km}$ east of Manaus, Amazonas on AM-010 highway (Fig. 1). A small stream in a clearing around $500 \mathrm{~m}$ from the Base $\left(02^{\circ} 45^{\prime} 33^{\prime \prime} \mathrm{S}\right.$ and 59 $\left.51^{\circ} \mathrm{\prime} 03^{\prime \prime} \mathrm{W}\right)$ was selected for the experiment.

The local climate provides permanently hot and humid conditions, classified by Köppen (1948) as a typical climate of the Amazon basin. The vegetation surrounding the clearing is tropical humid "terra-firme" forest, with trees reaching up to $40 \mathrm{~m}$ height (Lechtchaler 1956, Aubréville 1961).

Temperature and relative humidity were measured at 30 min intervals in the experimental site.

The observations were conducted monthly from April 1997 to March 1998, from 05:30 to 18:30 p.m. during two consecutive days. The diurnal and annual activity was determined by the number of tabanid attacks on the hosts. Collections were made using entomological nets. During the observation period, the caiman was kept tied and the anaconda was kept in a cage, covered with $2 \mathrm{~cm}$ mesh. Both were partially submerged in a small stream.

The descriptions of attacking behavior of the horse flies, preference for landing places and host defense were made in field observations. Captured tabanids were identified in the field by the second author, mounted with entomological pins, labeled and deposited in the invertebrate collection of the Instituto Nacional de Pesquisas da Amazônia.

\section{RESULTS AND DISCUSSION}

During one year of observation, 254 tabanids were collected, 40 on the anaconda and 214 on the caiman. Only four species were recorded during the experiment: 


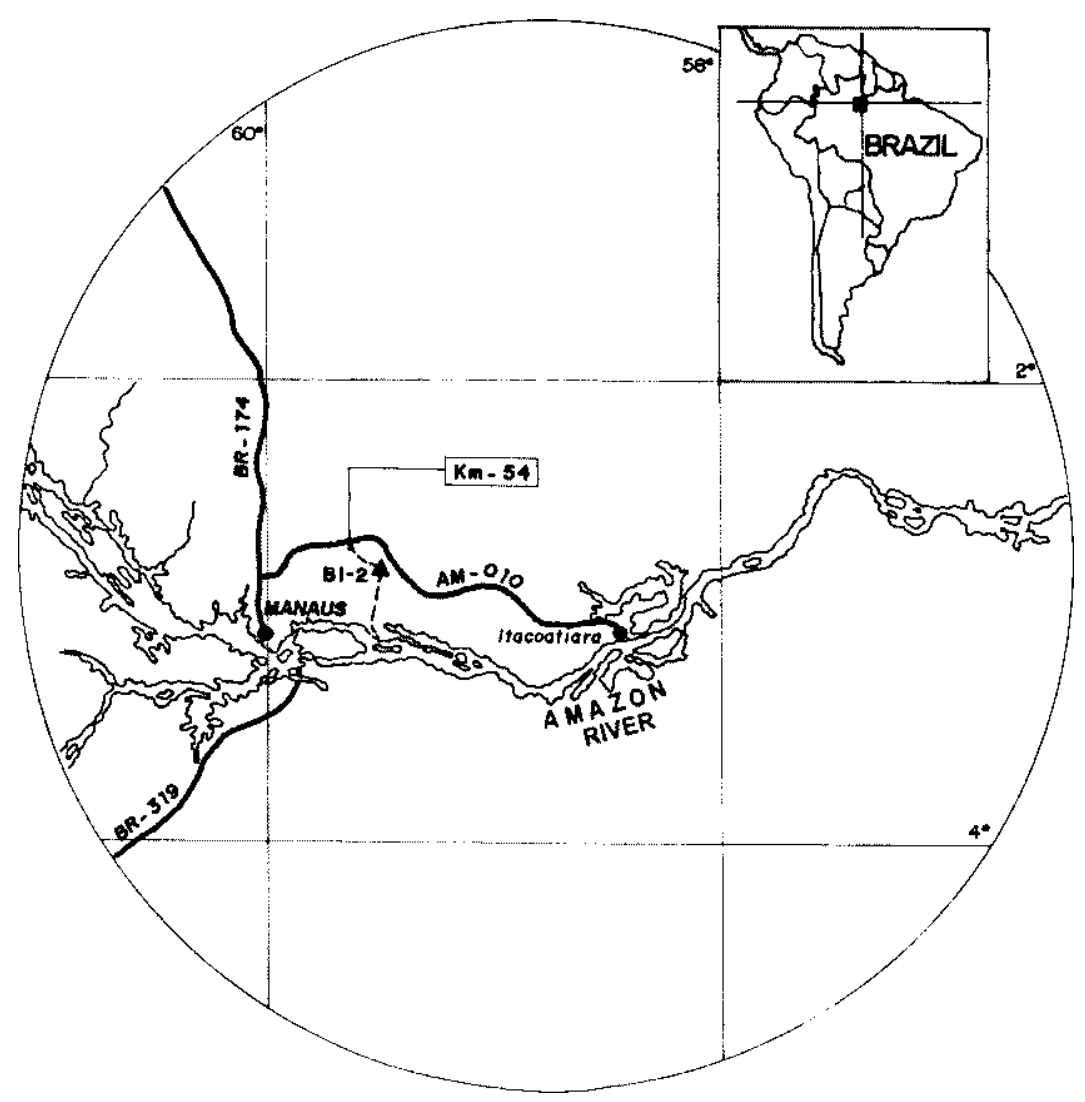

Fig. 1: map showing the collection locality, Base for Instruction of Forest War at the Manaus-Itacoatiara highway.

Stenotabanus cretatus Fairchild, S. bequaerti Rafael, Fairchild \& Gorayeb, Phaeotabanus nigriflavus (Kröber) and Tabanus occidentalis Linnaeus, all attacking both hosts. S. cretatus and T. occidentalis were the most abundant species with 123 and 61 specimens respectively. The remaining species totalled with 35 specimens each.

The majority of diurnal activity occurred in the hours with lower humidity and higher temperature. S. cretatus was an exception, because it was present throughout the day and increased in abundance in the early evening (Fig. 2)

During the year the occurrence of all species was almost completely restricted to the dry season. The only exception was T. occidentalis, which occurred during the whole sampling period and was more frequently observed at the end of the dry season (Figs 3, 4).
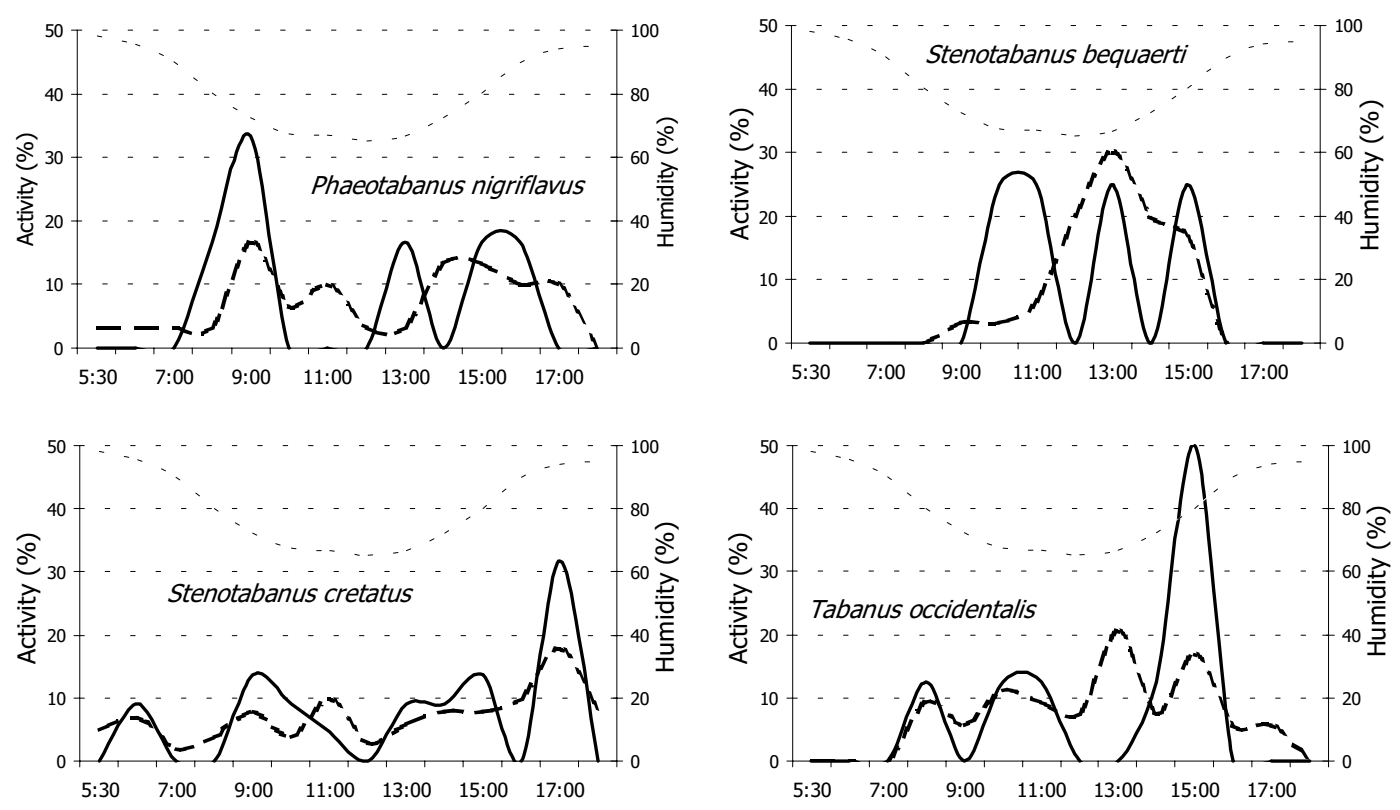

Fig. 2: frequency of four horse fly species in attacking alligator $(-)$ and anaconda (- - -) related to the humidity during observations at Base for Instruction 2, Manaus, Amazonas. 


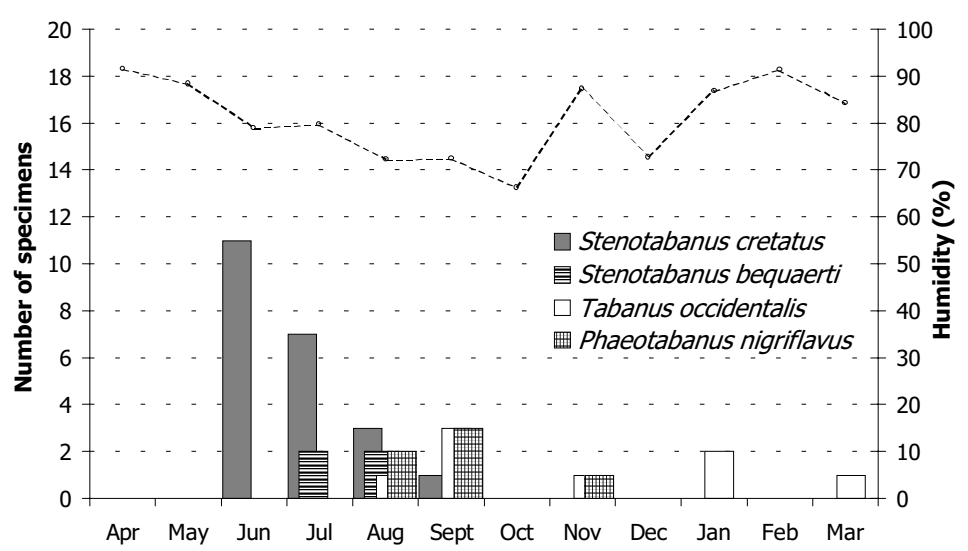

Fig. 3: activity of four horse fly species (Diptera), collected on anaconda from April 1997 to March 1998 at Base for Instruction 2, km 54, AM-010 Manaus, Amazonas with relative humidity.

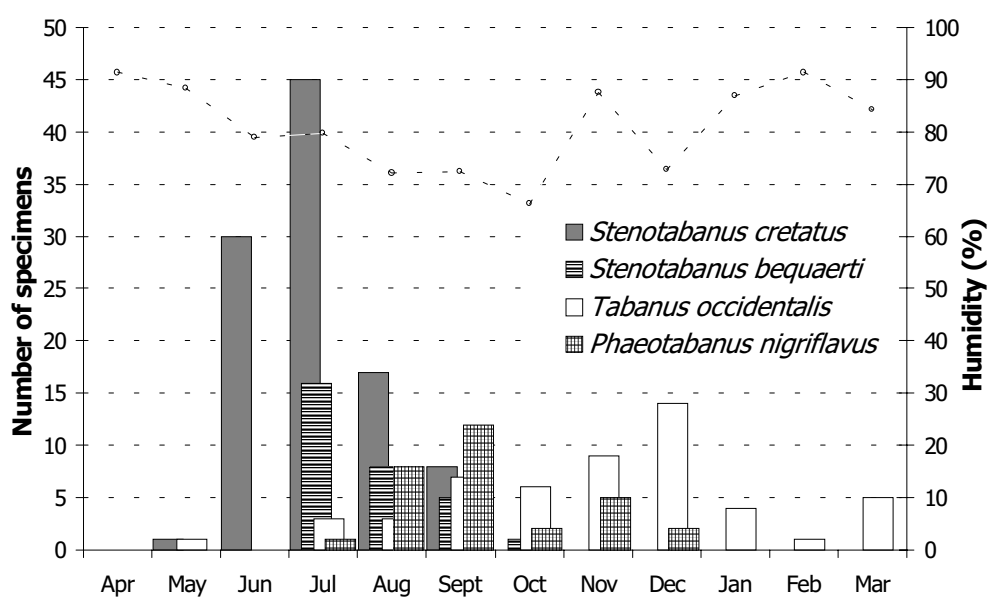

Fig. 4: activity of four horse fly species (Diptera), collected on alligator from Apri 1997 to March 1998 at Base for Instruction 2, km 54, AM-010 Manaus, Amazonas with relative humidity.

The preferred landing and feeding area on each host was observed for the four tabanid species (Figs 5,6). We observed that $S$. cretatus was visually attracted to the reptiles, when seeking a blood meal. After landing, it walked along the body of the animal, without defining a feeding place. Frequently it was captured in the sucking position, always on the head of the hosts, but it was never collected in a blood-filled state.

For all of the tabanid species, we observed circular and fast flight before settling on the head or other place chosen for landing and blood feeding. At the moment the tabanid selected the desired place and started feeding, we noticed a tenseness of the host. Caiman near the water dived or showed visible irritation, beating with the tail in an attempt to dislodge the pest flies. This behavior was aggravated when four or five tabanids attacked at the same time on the head and snout, as in the case of $S$. cretatus. Anaconda appeared to be bothered and, if the snake began moving or dived to dislodge, the tabanid resumed its attack immediately after the host reemerged.

The adult flight activity of the majority of the species has been recorded from June to December, the dry season in the Central Amazon Basin. In this season the water level of rivers and lakes is lower and the reptiles are more easily seen. The feeding place on the hosts, head and back, sug- gests that the tabanids can feed when the reptiles are in the water because the head stays above the water surface.

Aditional observations on the attack of tabanids on dead caimans were conducted in Cruzeiro do Sul, Acre 7³7'02"S, 7246'15"W, in November 1996. A common caiman was captured to be used as bait for tabanids, but was dead on the morning of the following day. At 09:30 we recorded the attack of T. occidentalis, at 09:40, Diachlorus curvipes, at 12:30, two individuals of T. occidentalis and one of $P$. nigriflavus, and finally, at 15:30 two individuals of $T$. occidentalis and one of $P$. nigriflavus.

\section{ACKNOWLEDGEMENTS}

To the Centro de Instrução de Guerra na Selva for logistical help. To Stefan Keppler and Flávia Costa for suggestions on manuscript and João Vidal for field support.

\section{REFERENCES}

Aubréville A 1961. Estude Écologique des Principales Formations Vegetales du Bresil et Contribuition a la Connaissance des Forets de L' Amazonie Bra-silienne, Centre Technique Forestier Tropical, Nogent Sur-Marne, France, 268 pp.

Barros ATM 1996. Seasonality of Phaeotabanus fervens (Diptera:Tabanidae) in the Pantanal region, Brazil. Mem Inst Oswaldo Cruz 91: 159.

Henriques AL, Ferreira, RLM, Vidal JF, Rafael JA 2000. 
Betrequia ocellata Oldroyd (Diptera, Tabanidae, Rhinomyzini) blood feeding on Caiman crocodilus (Linnaeus) (Crocodylia, Alligatoridae) in Manaus, Brazil. Revta Bras Zool 17: 609-613.

Köppen W 1948. Climatologia com un Estudio de los Climas de la Tierra. Fondo de Cultura Economica-Pánuco, Mexico, 479 $\mathrm{pp}$.

Lechthaler R 1956. Inventário das árvores de um hectare de terra firme da zona "Reserva Ducke", município de Manaus. Inpa Série Botânica 3: 1-7.

Medem F 1981. Tabanids (Diptera: Tabanidae) as ectoparasites on caimans (Crocodylia: Alligatoridae) in eastern Colombia. Cespedesia 10: 123-191.
Oldroyd H 1954. The Tabanids (Diptera: Tabanidae) of the Ethiopian Region. Vol. II, Tabanus and Related Genera, British Museum (Natural History), London, 341 pp.

Oliveira FL 1998. Phorcotabanus cinereus (Wiedemann) (Diptera: Tabanidae), uma Espécie de Mutuca Ornitofilica na Amazônica Central, Brasil, Thesis, Instituto Nacional de Pesquisas da Amazônia, Manaus, 38 pp.

Philip CB 1983. A unique, divergent developmental dependence of a Galapagos tabanid (Diptera, Tabanidae). Wasmann $J$ Biol 41: 47-49.

Philip CB 1986. A collection of four species of Tabanidae flies taken from a anaconda snake in Peru in May 1984. Pan Pac Entomol 63: 23. 